\title{
Syrenizm: poezja Julii Fiedorczuk
}

Monika Rudaś-Grodzka

TEKSTY DRUGIE 2020, NR 5, S. 399-418

DOI: 10.18318/td.2020.5.24 | ORCID: 0000-0002-2939-9583

$\mathbf{P}$ o 1989 roku literatura pisana przez kobiety musiała zmierzyć się nie tylko z transformacją polityczną, ale także ze zmianami w sferze kultury. Do szerszego obiegu weszła zachodnia krytyka feministyczna, odwołująca się do poststrukturalizmu, marksizmu czy psychoanalizy. Sprzyjało to ożywieniu intelektualnemu w następnych latach. Uczestniczyły w nim pisarki/poetki wywodzące się ze środowiska akademickiego. Z zagranicy wraz z teorią przybyły też mity, które szybko i na dobre zadomowiły się w polskiej krytyce i literaturze. Oprócz repertuaru narodowego, zapewniającego stałą obecność matki-Polki, rycerza-dziewicy, w nowej postaci pojawiły się wyobrażenia „czarownicy”, „wariatki/szalonej”, figury Demeter i Kore, Kopciuszka, Ofelii, a także Ateny. Jednak przede wszystkim swoje feministyczne piętno odcisnęły wszelkiego rodzaju prządki: Arachne, Mojry, wyrażające różne strategie kobiecego pisarstwa, sprawczości i tożsamości.

1 Literatura dotycząca tego tematu jest pokaźna: M. Janion Kobiety i duch inności, Sic!, Warszawa 1996; K. Kłosińska Kobieta autorka, w:
Monika Rudaś-

-Grodzka - profesor IBL PAN, historyczka literatury XIX i XX w.

Kieruje zespołem

Archiwum Kobiet IBL PAN. Powołała do istnienia dwie serie wydawnicze "Lupa obscura" i „Archiwum Kobiet. Dokumenty" IBL PAN. 
W tym przejściowym okresie można mówić o kilku przejawach myślenia mitycznego. Nie znikają tradycyjne ujęcia mitu, odwołujące się do bliższej i dalszej przeszłości, służące jako egzempla, alegorie czy maski autorskie. Współistnieją one z próbami tworzenia nowej kobiecej mitologii. Raz lepszymi, raz słabszymi. Największym zagrożeniem dla samej oryginalności literackiej okazały się "podręczne" narracje z gotowymi interpretacjami wyrastającymi z krytyki feministycznej.

Najciekawszy wydaje się nurt demitologizujący, ukazujący rozpad dawnych struktur narracyjnych, a także starający się włączyć się w nową rzeczywistość, aby ostatecznie ją przemodelować. W jego ramach można odnaleźć kierunek poszukujący nowego języka poetyckiego, badający granice wypowiedzi, testujący znaczenia, dekonstruujący klisze, pracujący nad poszerzeniem świadomości obywatelskiej, rozumiejący wielowymiarowo polityczność sztuki². Poezja ta korzysta też z bogatego repertuaru figur mitycznych, ale najczęściej po to, żeby konfigurować stare i wytwarzać nowe sensy.

Z tego względu warto przyjrzeć się twórczości Julii Fiedorczuk (ur. 1975), poetki, pisarki, krytyczki, akademiczki. Od 1998 roku wykłada ona literaturę amerykańską i teorię literatury w Instytucie Anglistyki Uniwersytetu Warszawskiego. Ceniona jest jako autorka prac poświęconych ekopoetyce. Wystarczy tu wymienić dwie książki: Ekopoetyka a konwencje poezji amerykańskiejXX wieku oraz Ekopoetyka (wspólnie z Gerardo Beltránem) opublikowane w 2015 roku. Wielokrotnie nominowana do wielu nagród (Nagroda Nike 2016, Silesius 2018). Za poetycki debiut Listopad nad Narwia (2000) otrzymała Nagrodę Polskiego Towarzystwa Wydawców Książek, jest ponadto laureatką Nagrody Poetyckiej im. Wisławy Szymborskiej (2018). Do chwili obecnej wydała następujące tomy wierszy: Bio (2004), Planeta rzeczy zagubionych (2006), Tlen (2009), tuż-tuż (2012), Psalmy (2017).W 2010 roku ukazał się zbiór opowiadań

Ciało i tekst. Feminizm w literaturoznawstwie - antologia szkiców, red. A. Nasiłowska, Wydawnictwo IBL PAN, Warszawa 2001, s. 94-116; tejże Ciało, pożądanie, ubranie. O wczesnych powieściach Gabrieli Zapolskiej, eFKa, Kraków 1999; tejże Fantazmaty. Grabiński - Prus - Zapolska, Wydawnictwo UŚ, Katowice 2004; tejże Feministyczna krytyka literacka, Wydawnictwo UŚ, Katowice 2010; K. Szczuka Kopciuszek, Frankenstein i inne. Feminizm wobec mitu, eFKa, Kraków 2003; G. Borkowska Cudzoziemki. Studia o polskiej prozie kobiecej, Wydawnictwo IBL PAN, Warszawa 1996; M. Świerkosz Arachne i Atena. Literatura, polityka i kobiecy klasycyzm, Wydawnictwo UJ, Kraków 2017.

2 Zob. J. Fiedorczuk, J.G. Beltrán Ekopoetyka. Ekologiczna obrona poezji, Instytut Studiów lberyjskich i lberoamerykańskich UW - Muzeum Historii Polskiego Ruchu Ludowego, Warszawa 2015. 
Poranek Marii i inne opowiadania, a następnie inne utwory prozatorskie: Biata Ofelia (2011), Nieważkość (2015), Bliskie kraje (2016).

Przez krytyków jej poezja oceniana jest jako chłodna, intelektualna, samoświadomowa ${ }^{3}$, sama poetka zaś temu nie zaprzecza i podkreśla w wywiadach, że bardzo ceni "precyzję" i swoje akademickie poetyckie zaplecze. Fiedorczuk znana z tego, że komentuje swoją twórczość, w wywiadzie w „Dwutygodniku” powiedziała: „staram się integrować wrażliwość artystyczną i naukową”. Joanna Grądziel-Wójcik wpisuje poetkę w nurt neoawangardy i zwraca uwagę na „wielopunktowe konstelacje programu” Fiedorczuk: „na twórczość tej autorki składają się różnogatunkowe wypowiedzi (nie tylko) literackie, pełniące rolę paratekstów dla poezji, których sednem pozostaje autorefleksyjny, metakrytyczny i postulatywny stosunek do sztuki słowa. Pamiętać jednak trzeba, że ta wielonurtowa aktywność, choć spięta ekopoetycką klamrą, nie musi układać się w spójną całość - nieprzypadkowo Fiedorczuk sięga po różne formy"5.

Intelektualizm jej poezji sąsiaduje ze zmysłowością, lirycznością, zaangażowanie w problemy środowiska z namysłem nad istotą języka, a konwencja erotyków zderza się z odniesieniami do współczesnej fizyki czy filozofii. Stałym ogniwem tych wszystkich połączeń jest kobiecość, o której poetka mówi: „Nie wyobrażam sobie pisania wyzutego z płci: piszę zawsze jako kobieta. Podobnie, nie wyobrażam sobie, aby ktokolwiek, kto jest matką, mógł tę część doświadczenia zupełnie oddzielić od tej swojej części, w której jest poetką"6. Fiedorczuk nie stara się eksponować swojej kobiecości, często ograniczając się do miękkości i płynności metaforyki. Podkreślany przez nią przy różnych okazjach ten punkt widzenia należy rozumieć jak miejsce alternatywne

3 Do najważniejszych prac dotyczących poezji Fiedorczuk należą: J. Grądziel-Wójcik Konstelacje neoawangardy w poezji kobiet na przykładzie twórczości Julii Fiedorczuk, „Zagadnienia Rodzajów Literackich" 2018 LXI, z. 2, DOI: 10.26485/ZRL/2018/61.2/9; tejże „Instrukcja obsługi kobiety iświata”. O (eko)poezji Julii Fiedorczuk, „Poznańskie Studia Polonistyczne. Seria Literacka” 2018, 33 (53), s. 237-132; A. Węgrzyniak Ćwiczenia ekologicznej wyobraźni. O poezji Julii Fiedorczuk, „Poznańskie Studia Polonistyczne. Seria Literacka" 2018 nr 33 (35), s. 219-235; E.E. Rajewska Abulia i energia. O pewnym wierszu Julii Fiedorczuk (dla Elizabeth Bishop), w: Formy (nie)obecności. Szkice o współczesnej poezji kobiet, red. J. Grądziel-Wójcik, A. Kwiatkowska, E. Sołtys-Lewandowska, Universitas, Kraków 2018, s. 333-347.

4 Zob.https://www.dwutygodnik.com/artykul/6613-az-cala-ja-zezremy.html.

5 J. Grądziel-Wójcik Konstelacje..., s.124.

6 Zob. www.literaturajestsexy.pl/mysle-ze-takie-tematy-sa-dwa-seks-i-smierc-rozmowa-z-juliafiedorczuk. 
wobec patriarchalnego pisania.Udowadnia, że jej poezja nie musi być męska, żeby uznać ją za dobrą, wystarczy, że jej twórczość ma charakter intelektualny: „Właściwie myślę przede wszystkim wtedy, kiedy piszę. I chyba po to właśnie piszę, żeby intensywniej - i systematyczniej - myśleć"7. Najważniejszy jest dla niej związek pisania i życia. W rozmowie z Oleną Sheremet (13 stycznia 2014 roku) przyznała, że deklaracja: ,jestem poetką”, to akt odwagi w świecie wydawniczym zdominowanym przez mężczyzn, ujawnianie płci ma swoje polityczne konsekwencje. Traktuje więc pisanie jako walkę nie tylko na niwie języka, ale również w przestrzeni publicznej ${ }^{8}$.

W wywiadach Fiedorczuk dużo miejsca poświęca swoim naukowym inspiracjom, zainteresowaniom, wielokrotnie powtarza, że wychowała się na angloamerykańskim modernizmie i chociaż sama widzi się jako postmodernistkę, jej mistrzami są: Ezra Pound, William Carlos Williams, Marianne Moore, Laura Riding, Mina Loy, Hilda Doolittle. Można odnieść wrażenie, że ich twórczość była dla niej lekcją pisania własnej poezji. Ich programy poetyckie, widzenie świata zbiegają się z jej światopoglądem, rozumieniem poezji, ekopoetyki, etyki i przede wszystkim języka. Za sprawą tych powinowactw w jej rozumieniu i praktyce poezja musi pozostać nieprzejrzysta, niejednoznaczna, z tego względu, że rzeczywistość zawsze pozostaje dla nas niedostępna. Język może być zapisem utraty albo tęsknoty za umykającą nam rzeczywistością, źródłem energii, pragnienia istnienia („to energia erotyczna, miłosna i dzika" ${ }^{\prime \prime}$. Fiedorczuk mówi o konieczności angażowania się, literatura poprzez swoją wrażliwość ma obowiązek wobec naszego świata, podkreśla, że poezja nie sprowadza się sama do siebie, nie jest autonomiczna, nie może być egoistyczna, ale ma być gestem, działaniem, odpowiedzialnością za życie na Ziemi, ma być wspólnym domem dla wszystkich ludzi i nie-ludzi, a wiersz powinien być jednym ze sposobów zamieszkiwania tej wspólnej przestrzeni ${ }^{10}$.

Takie podejście każe nam zastanowić się nad głębszymi, bardziej niedostępnymi pokładami poezji Fiedorczuk. Ona sama zwraca uwagę swoim czytelnikom na figuratywny charakter języka, na używane przez nią liczne

7 Cytat z wywiadu z Julią Fiedorczuk Milczenie jest częściq̨ rozmowy 2010: b.s.za: J. Grądziel-Wójcik Konstelacje neoawangardy...

8 Zob. http://popmoderna.pl/byc-moze-wcale-nie-jestem-poetka-wywiad-z-julia-fiedorczuk/.

9 Zob. https://ksiazki.wp.pl/kobiety-to-tez-ludzie-z-julia-fiedorczuk-rozmawia-bartosz-czartoryski61459587879584010. 
tropy retoryczne ${ }^{11}$. Chciałabym zwrócić uwagę na dwie przywoływane przez nią metafory, które są zakorzenione w mitach. Pająk tkający sieć jest ważną metaforą poetyckiej ekspresji, prowadzącą do wielu mitów o Arachne. Poetka podaje nam klucz do swojej twórczości:

Jestem głęboko przekonana o wzajemnych powiązaniach pomiędzy różnymi elementami rzeczywistości, pomiędzy istotami, zjawiskami i procesami. Odczuwam to czasem bardzo silnie. Myślę też, że twórczość natury, naturalna poesis - sztuka pająka tkającego sieć, twórczość rzeki rzeźbiącej koryto - jest krewniaczką ludzkiej wyobraźni, która tworzy obraz, wiersz, a może nawet wizję polityczną... ${ }^{12}$

Innym mitem, który przywołuje, jest historia o Echu opowiedziana przez Owidiusza. Użyła go jako tytułu utworu, będącego aluzją do villanelli One art Elizabeth Bishop. Wiersz Fiedorczuk ma być w sensie dosłownym echem, wyzwalać skojarzenia sensualne. Nie niesie on negatywnych znaczeń, jego mimetyczny charakter ma nawiązywać dialog z villanellą. Przede wszystkim jest wyrazem uwielbienia i szacunku polskiej poetki dla amerykańskiej:

Echo to imię nimfy, która znikła z powodu nieodwzajemnionej miłości do Narcyza, ale także metafora tej utraty znaczenia w języku [...].W wierszu Echo zależało mi przede wszystkim na tym, żeby opowiedzieć historię pewnej konkretnej miłości. Według najbardziej znanej wersji tego mitu, Echo zaczęła zanikać, kiedy Narcyz wzgardził jej uczuciem. Było jej coraz mniej, aż wreszcie został sam głos. W dodatku zła bogini zabroniła jej mówić we własnym imieniu i Echo musiała już zawsze tylko powtarzać to, co powiedzieli inni. To jest bardzo przejmująca opowieść o braku miłości i o marginalizacji. ${ }^{13}$

W twórczości Fiedorczuk można odnaleźć inne bardziej niejednoznaczne odniesienia do mitów, w dużym stopniu określające strukturę jej wyobraźni. Należy do niej hybrydyczność, polegająca na łączeniu heterogenicznych elementów. Hybrydyczność jej poezji to z jednej strony płynność - z drugiej

\footnotetext{
11 Zob. www.dwutygodnik.com/artykul/5964-powrot-do-swiata-trzeci-pejzaz.html.

12 Zob.www.dwutygodnik.com/artykul/6613-az-cala-ja-zezremy.html.

13 Zob. www.biuroliterackie.pl/biblioteka/wywiady/cieple-rzeczy/.
} 
zerwania, przejścia z widzenia z małej odległości na spojrzenie z perspektywy lotu ptaka oraz brak syntezy, niepełność, sprzeczny charakter widzenia i rozumienia. Forma ta ukrywa się na wielu poziomach jej życia twórczego i naukowego. Już za pierwszy znak można uznać połączenie akademickiej pracy i artystycznej twórczości. Fiedorczuk nie widzi w tym sprzeczności i podkreśla, że jej twórczość i praca naukowa funkcjonują na zasadzie osmozy, wnikają w siebie, tworząc nowe jakości. W moim rozumieniu w hybrydyczności, w dalszej części nazywanej przeze mnie syrenizmem, nie chodzi o sprzeczność, ale o miejsce styku różnych elementów i związany z tym rodzaj połączenia. Zasadniczą sprawą jest sposób i moment spajania odmiennych, niepasujących do siebie składników.

Zanim przejdę do wyjaśnienia tego zjawiska, chciałabym zaznaczyć, że należy powstrzymać się od traktowania prac naukowych Fiedorczuk jako przewodnika po wierszach, gdyż ona sama unika budowania łatwych przejść, a wręcz zastawia pułapki na czytelników i czytelniczki idących na skróty. Często taki pomost wisi nad przepaścią, gdyż zbudowany jest do połowy, i trzeba się zatrzymać, aby dokonać skoku, albo należy się cofnąć na brzeg i przyznać do bezradności. Warto jednak chociaż na wstępnym etapie skorzystać z tej bardzo dobrze opracowanej przez nią drogi, by zobaczyć, dokąd nas doprowadza. Fiedorczuk umiejscawia się pomiędzy wieloma dyscyplinami: literaturą, nauką, krytyką literacką i filozofią. Głównym obszarem jej zainteresowania jest ekopoetyka rozumiana nie tylko jako teoria, ale także odrzucająca iluzję powrotu do natury „interdyscyplinarna praktyka współtworzenia ludzkiego i nieludzkiego świata"14. Stąd w jej refleksji teoretycznej można odnaleźć tendencje do dekonstruowania tradycyjnych mitów o naturze i poszukiwania nowego języka, który pozwalałby na współistnienie tego, co ludzkie i nie-ludzkie. W książce Cyborg w ogrodzie stawia pytanie: „jakie są możliwości w obliczu aktualnego kryzysu ekologicznego ${ }^{15}$. I metaforycznie odpowiada: „Wiersz jest takim chwilowym kosmosem, praktyczną lekcją nowych sposobów bycia"16

Dla Fiedorczuk tworzenie, stawanie się, znikanie, bycie to cechy współczesnej poezji, która jest miejscem, gdzie pleni się nieokiełznaność, widziana przez nią jako zjawisko najbardziej pożądane i pociągające (H.D. Thoreau

\footnotetext{
14 J. Fiedorczuk Cyborg w ogrodzie. Wprowadzenie do ekokrytyki, Wydawnictwo Naukowe KATEDRA, Gdańsk 2015, s. 1.

15 Tamże, s. 108.

16 Tamże, s. 138.
} 
Walking „W literaturze pociąga nas tylko to, co dzikie”17.) Jednakże dzikość nie oznacza dla niej tradycyjnie pojmowanej przyrody ${ }^{18}$. Pytanie o to, gdzie znaleźć można to, co nieoswojone, jest zasadne, gdyż nie ma już terenów wolnych od ingerencji człowieka. Za Garym Snyderem Fiedorczuk odpowiada: „[dzikość] jest wszędzie; niemożliwe do usunięcia kolonie grzybów, mchu, pleśni, drożdży, i tym podobnych organizmów, które nas otaczają i mieszkają w nas. Myszy za domem, jelenie na autostradzie, pająki po kątach, ludzkie ciało to dzikie terytorium, podobnie język"19. Odwołuje się ona do poezji Thoreau zafascynowanego tym, co nieoswojone: przywołuje jego słowa, które wydają się jej bardzo bliskie: „najdziksze żyje najbardziej”. I dodaje: „dostrzegał on zadziwiające analogie pomiędzy rozmaitymi formami natury a wytworami ludzkiej myśli, widział wzajemne przenikanie się, to, co John Cage nazywał nieskrępowaniem wszystkich rzeczy"20.

Poezja jest dla niej przede wszystkim eksplorowaniem dzikości języ$\mathrm{ka}^{21}$. Szuka miejsc, gdzie styka się ciało, umysł i rzeczywistość, bo tam język w sposób nieskrępowany może się rozwijać, stając się transcendentalnym doświadczeniem $^{22}$. Dlatego też poezja, według Fiedorczuk, powinna drwić z mitów i pozostać nieokrzesaną, by móc wymyślać nowe sposoby komunikacji. Autorka Tlenu wierzy, że na planecie zagrożonej zagładą tylko poezja może nas zbawić (zbawiać i pozwalać żyć). W wielu jej wierszach pojawia się związek między słowami a wodą i słońcem. Poezja (poiesis) jest tworzeniem, podobnie jak dzika natura jest tworzeniem autopoiesis, $\mathrm{np}$. w procesie fotosyntezy ${ }^{23}$.

Naukowemu i artystycznemu działaniu Fiedorczuk towarzyszy pragnienie demaskacji anachronicznego charakteru wierzeń dotyczących mitów

17 Tamże, s. 20.

18 „Czy jednak określenie «dzika przyroda» może mieć jakiekolwiek zastosowanie w czasach, kiedy właściwie każdy zakątek Ziemi nosi ślady ludzkiej działalności, w postaci miast, szlaków komunikacyjnych, pól uprawnych, a także zanieczyszczeń obecnych w ziemi, wodzie, powietrzu. $\mathrm{Na}$ to pytanie odpowiada Rebecca Raglon [...] wprowadzając pojęcie dziczy antropogenicznej (anthropogenicwildness)" (J. Fiedorczuk Cyborg w ogrodzie, s. 62).

19 J. Fiedorczuk Cyborg w ogrodzie, s. 59.

Tamże, s. 58.

Tamże, s. 59.

Tamże, s. 60. 
o naturze. Dlatego unika poetka tonu moralizatorskiego, poszukuje języka pozwalającego wyrazić związki między poezją a środowiskiem naturalnym i wierzy w siłę wyobraźni ekologicznej podważającej opozycje: natura/kultura, cywilizacja/dzicz. Jej zdaniem podstawowe zadanie ekokrytyki „badanie i rozmontowywanie skostniałych konstrukcji konceptualnych dotyczących pozaludzkiej natury" i zdaje sobie sprawę, że jest to bardzo trudne, ponieważ ludzkie konstrukcje wyobrażeniowe i pojęciowe mają dużą żywotność, zwłaszcza jeśli dotyczą kwestii tak ściśle związanych z definicją człowieczeństwa, jak relacja między ludźmi a tym, co nie-ludzkie ${ }^{24}$.

Jako badaczka i poetka uważa Fiedorczuk, że rozmontowanie mitu natury jest konieczne. Postrzeganie natury, którą człowiek darzy miłością i nienawiścią, pozostaje bowiem uwarunkowane kulturowo ${ }^{25}$. Opozycja natura/ kultura ma charakter teologiczny i metafizyczny. Natura, będąca ludzkim wyobrażeniem, jest miejscem produkowania różnych fantazmatów i niewiele ma wspólnego z rzeczywistością, dlatego Fiedorczuk postuluje obalenie dominujących mitów. Najgroźniejsze są dwa: pierwszy mówiący, że natura jest upadłym rejonem bytu, domeną konieczności, z której może wyłamać się tylko człowiek. Drugi, równie trujący, snuje opowieść o utraconym raju najmocniej określający zachodnią kulturę. Eden jest narcystyczną projekcją psychologiczną wynikającą z potrzeby ładu, bezpieczeństwa i sytości (Fiedorczuk, Cyborg w ogrodzie, s. 148).

Mimo usilnego demaskowania mitów i fantazmatów Fiedorczuk ma świadomość, że nie tak łatwo się od nich uwolnić, szuka więc form bardziej otwartych, dających nadzieję na ich rozwój lub możliwość porzucenia. Widać to w jej stosunku do różnych prądów feministycznych, odcina się bowiem od boginicznego ekofeminizmu i esencjalizmu utożsamiającego kobietę z naturą, ciałem czy rozrodczością, szukając dla siebie miejsca w micie cyborgicznym, ujawniającym paradoksy tożsamości kobiecej i nie tylko ${ }^{26}$. Fiedorczuk

24 Tamże, s. 14.

Tamże, s. 93.

Dostrzega w Manifeście cyborga („Socialist Review” 1985) Donny Haraway źródło inspiracji poetyckiej "Cyborg to organizm cybernetyczny, hybryda zawierająca elementy maszyny i organizmu, stworzenie odzwierciedlające rzeczywistość społeczną, a zarazem fikcyjną". Ale cyborg jest też użytecznym narzędziem krytyki - dzięki niemu odsłania się pokraczność człowieka, który w pędzie do zdominowania natury jawi się jako bóg z protezami" (J. Fiedorczuk Cyborg w ogrodzie, s. 184). "Człowiek-cyborg z jednej strony jako produkt uboczny technologizacji może kontestować zastane role społeczne, ale z drugiej jest fundamentalnym elementem kondycji ludzkiej jako takiej, czy tego chcemy, czy nie" (tamże, s. 184). 
w swoich pracach teoretycznych dostrzega w hybrydycznym organizmie cybernetycznym, zawierającym elementy maszyny i organizmu, potencjalność rozumianą jako model istnienia. Ta nowa ontologia pozbawiona początku, unikająca jedności, nie dokonuje cięć między rzeczywistością materialną a wyobraźnią. Poetkę pociąga przestrzeń między bios i techne, jej nie do końca poznane granice. Jej ulubionym słowem, mimo mitologicznych konotacji, jest ogród. Pojawia się on też często w jej poezji. Nie oznacza powrotu do raju, ale raczej miejsce pomiędzy. Ogród dla poetki „podobnie jak cyborg, jest hybrydą - połączeniem naturalności i sztuczności, bios i techne"27.

Fiedorczuk w swoich pracach teoretycznych zapewnia, że szuka miejsc najbardziej dzikich, by móc uprawiać poezję. Oczkiwalibyśmy więc od jej wierszy manifestacji wolności, nieskrępowania, żywiołowości. Ale nie, na dzikich terenach zakłada ogrody; narzuca pewien rygor swojemu językowi, nie pozwala na żadne ekscesy: zamiast ekstazy raczej: asceza i precyzja. Ten rodzaj antynomiczności dzikości i ładu przywołuje na myśl zabiegi Gelsominy, bohaterki La Strady, która w miejscach odludnych, nienależących ani do miasta, ani do wsi, gdzieś przy drodze sadziła pomidory. Gelsomina, choć sprzedana wędrownemu artyście Zampano, objeżdżającemu miasteczka starym motorem z amerykańskiego demobilu, jest dzika i dziwna. Jest czystą poezją, ale w świecie, w którym przyszło jej się urodzić, przeznaczono jej rolę clowna grającego na bębenku, rozśmieszającego publiczność. Jej namalowany uśmiech, prawdziwe łzy tworzą sploty hybrydalne wokół tej postaci. Jej osobliwość, hybrydyczność odzwierciedla syrena wymalowana na budzie cyrkowej Zampana. Ta postać ludzko-nieludzka: kobieta-ryba jest kluczem również do poezji Fiedorczuk.

W twórczości polskiej poetki uderza mnogość motywów akwatycznych, które są nieustannie demitologizowane i remitologizowane. Aspekt uwalniający skojarzenia ze sferą nieświadomości, konotujący cielesność i doświadczenie kobiece jest dobrze rozpoznany przez krytykę feministyczną, postrzegającą wodę jako przestrzeń dla wyrażenia kobiecej podmiotowości. Jednak dla Fiedorczuk woda jest materią poetycką. Tam właśnie można dostrzec strategię twórczą, wstępnie nazwaną przeze mnie syrenizmem, polegającą na łączeniu dwóch lub więcej niepasujących elementów. Jest to o tyle istotne, że ich wartość należy postrzegać nie tylko przez pryzmat tworzenia nowych form, ale także uchwycenia momentu przed ich związaniem oraz wyczucia miejsca „styku”. Dzięki temu odsłania się całe spektrum niedopasowania.

27 J. Fiedorczuk Cyborg w ogrodzie, s. 187. 
W wierszu Laury (Riding) Jackson $Z$ powodu ubrań przetłumaczonym przez Fiedorczuk ${ }^{28}$ czytamy:

Gdyby nie krawcy, którzy łączą

Dobrą wolę tułowia

Z kontenansem głowy,

Bylibyśmy jak dwa światy,

Nie świat i jego cień,

Ciało.

Głowa to jeden świat,

Ciało kolejny świat -

Taki sam, lecz powolniejszy,

Bardziej olśniony i wcześniejszy;

Tę rozbieżność koryguje

Ubranie

(Obrotycudów, 180).

Syrenizm to miejsce złączenia, w głębi którego kryje się jakaś nadmierna tkliwość i ból: „Czyż nie pamiętacie, jak bardzo cierpiała Mała Syrenka, kiedy chodziła - jakby chodziła po ostrzach noży - kiedy odrzuciła swój rybi ogon [...]" - pyta Laura Riding (Jackson) w opowiadaniu Korona dla Hansa Andersena, przetłumaczonym przez Fiedorczuk ${ }^{29}$.

Wiersze Fiedorczuk przypominają zdjęcia, które mają dużą ziarnistość, a więc charakteryzuje je znaczna rozdzielczość, jakby każda rzecz była przez nią powoływana na mocy wyjątku. Mimo precyzyjnych kadrów wiersze są pełne kontrastów, pęknięć, luk, niedopowiedzeń, zaskakujących zestawień. We wstępnej, niescalającej lekturze utworów, odnosimy wrażenie, że przestrzeń między rzeczami i poza nimi rozszerza się, płynie w sposób nieukierunkowany, co daje wrażenie obcości przedmiotom znanym i efekt bliskości rzeczom nieznajomym. Zestawia Fiedorczuk elementy, które na pierwszy rzut oka, nie mają z sobą nic wspólnego albo wydaje się, że znalazły się obok siebie całkiem przypadkowo. Ten pierwszy odruch zagubienia i nierozumienia

28 L. (Riding) Jackson Obroty cudów. Utwory wybrane: wiersze, przeł. J. Fiedorczuk, Biuro Literackie, Wrocław 2012.

29 L. (Riding) Jackson, Obroty cudów, s. 79. 
szybko zmienia się, dzięki pracy umysłowej per analogiam, w hybrydyczną całość mającą zaplecze w naszej umiejętności łączenia przeciwieństw ${ }^{30}$. Kiedy nasze pragnienie rozumienia zostanie zaspokojone i wyłaniają się spójne sensy pozwalające dostrzegać ich „jedność", rana, znajdująca się na styku łączonych części, staje się niewidoczna i przestajemy odczuwać kłujący niepokój.

Syrenizm jako postawę twórczą przeciwstawiającą się sile jednoczenia, spajania, tworzenia continuum, symetrii odnajdujemy w bezpośrednich wypowiedziach Fiedorczuk, która na pytanie, czy w symetrii świata ukrywa się odpowiedź na najważniejsze pytania, odpowiada przecząco i z przekorą:

J.W.: Podobno uważa Pani, że - to będzie cytat - w symetriach, analogiach i powtórzeniach zawiera się tajemnica wszechświata. Skąd takie, nieco ezoteryczne chyba, przekonanie? Z bycia zodiakalnymi, zawsze symetrycznymi Rybami [śmiech]?

J.F.: No widzi Pan, wczoraj były urodziny Karola Darwina, cały dzień mówili w radiu o teorii ewolucji (temat bardzo mi bliski) i dzisiaj mam ochotę głosić, że wszystko jest chaosem, nie ma żadnego porządku tylko przypadek, i że to jest niesamowite, że z tego jakimś cudem wyłaniają się spotkania, namiętności, pasje, cały ten piękny nonsens ludzkiej i nie tylko ludzkiej egzystencji. Symetria to zapewne kwestia percepcji. ${ }^{31}$

W rzeczy samej poezję Fiedorczuk charakteryzuje płynność, zmiana, transformacja, ciąłłe stawanie się, reprezentowane przez ocean, morze czy rzekę. Woda płynie przez jej wiersze i tworzy dla nich naturalne środowisko. Odsłaniane przez nią fantazmaty świata konsumpcji, np. w obrazie małej Syrenki przymierzającej legginsy ${ }^{32}$, sąsiadują z utopiami o miękkich, bezpiecznych „wklęsłościach". Wśród dominujących figur jej poezji odnaleźć można ryby, ptaki, syreny ${ }^{33}$.

30 Koncepcję nierozumienia zaczerpnęłam z książki G. Didi-Huberman Przed obrazem. Pytanie o cele sztuki, przeł. B. Brzezicka, słowo/obraz terytoria, Gdańsk 2011.

31 Zob. www.literaturajestsexy.pl/mysle-ze-takie-tematy-sa-dwa-seks-i-smierc-rozmowa-zjulia-fiedorczuk. „mała Syrenka przymierzy / lśniące legginsy. Będzie miała w sieci / Nylonową przyszłość" (Za górami, w: Bio, Biuro Literackie, Wrocław 2004, s. 240.).

33 Motyw płynności, zanurzania się pojawia się w Białej Ofelii Fiedorczuk, w scenie erotycznej między kobietami. To rodzaj fantazji, utopii miłości lesbijskiej: „Połóżmy się - powiedziała. Położyły się twarzami do siebie, splatając uda i dotykając stopami. «Masz zimne stopy - po- 
Kiedy byłam rybą

Kosmos jak zawsze okrągły

Miał przytulne ściany

Śniłam o boskich płetwach

Pióropuszach i życiu

Po wodzie

Mówiono ogon

Odpada ale jest nagroda

Para bolesnych stóp

Nie wierzyłam w bajki. Zapuściłam

Skrzydła jak liście

Czarnych paproci

Och gdzież ja nie byłam!

Kiedy byłam rybą

Nie było w ogóle dni,

Seksu, ani różnicy.

Ciepło przychodziło

Z zewnątrz teraz

Mam w płucach nieznośnie

Lekkie powietrze

Mam pokusę morza

W zielonych tęczówkach

$($ Bio, 12)

Poetka subwersywnie lokuje się między rybami, przeformułowując swoją zwierzęcą/nieludzką postać. W naszej patriarchalnej kulturze kobiecość i jej zwierzęce reprezentacje przedstawiane były jako monstra. Ta prowadząca do zakłócenia percepcji deformacja, która naznaczała kobiety demonizmem, wywoływała odruch obrzydzenia i zarazem fascynacji oraz dreszcz przerażenia na widok czegoś niesamowitego. Wyobraźnia już od antyku żywiła się takimi widokami z pogranicza jawy i snu. W Europie chrześcijańskiej obrazy mieszańców ludzko-zwierzęcych miały charakter religijny i służyły do stygmatyzacji grzeszników. Zniekształcone, nieproporcjonalne, zezwierzęcone

wiedziała Anna do Elizy, która gładziła ją po policzku. Wiem - powiedziała - Zawsze są zimne». Annie kręciło się w głowie; na przemian otwierała o przymykała oczy, myśląc: Płynie przez nas rzeka. Myśląc: Chcę się w tobie zanurzyć" (J. Fiedorczuk Biała Ofelia, Biuro Literackie, Wrocław 2011, s. 130). 
cechy hybrydalnego ciała ludzkiego zawsze miały być ostrzeżeniem i przestrogą - często znakiem kary Bożej oraz przypomnieniem, że występek, który wywołał jego gniew, trzeba odpokutować ${ }^{34}$.Z drugiej zaś strony na obrzeżach oficjalnej religii, pozostając sygnaturą innego porządku w świecie, monstrum jest istnieniem celowym. Dla Paracelsusa dziwy morskie są niczym komety, które Bóg ukazuje człowiekowi. Podkreślał on celowość istnienia monstrów, a więc nie były one dla niego antywartością życia, ale samym życiem ${ }^{35}$.

Niewątpliwie Fiedorczuk gra świadomie z tą konwencją nadającą kobiecie znaczenia negatywne i czyni z niej nową materię poetycką ${ }^{36}$. Dlatego możemy spojrzeć na ryby, w domyśle też syreny, jako na formy przejściowe i, choć w oficjalnej kulturze mogą wydawać się one zagrożeniem dla normy czy kanonu określającego to, co ludzkie, są raczej, tak jak inne monstra, innowatorkami na drodze prowadzącej do powstania nowych rozwiązań w naszym świecie.

Obudziłam się

I byłam kobietą

Od stóp, po końce włosów

[...]

Wstałam i miałam

Stopy

I czemuś dziesięć

Śmiesznie małych palców.

(Listopad nad Narwia, 31)

Warto spróbować odpowiedzieć na pytania: skąd wzięło się głębinowe marzenie o byciu rybą w poezji Fiedorczuk. W wierszu Fotosynteza czytamy:

A trzeba wyjść na ląd, opierzyć się i patrzeć

Prosto w słońce

$($ Bio, 6)

34 J.-J. Courtine Ciało nieludzkie, w: G. Vigarello Historia ciała, t. 1, słowo/obraz terytoria, Gdańsk 2011, s. 352-353.

35 Paracelsus O nimfach, sylfach, pigmejach, salamandrach etc., przeł. R. Urbański, Oficyna Wydawnicza ATUT, Wrocław 2013.

36 J. Fiedorczuk Listopad nad Narwiq, Biuro Literackie, Legnica 2000. 
W wierszu Lądy i oceany fantazja ta odsłania, dotyczącą praform zapisanych w pamięci komórkowej wszystkich żywych stworzeń, zbiorową intuicję o praczasach, a w sferze indywidualnej oznacza chęć otwarcia się na inne formy życia, okupioną często cierpieniem, a także pragnienie odczucia napięcia między tym, co jest, a tym, co mogłoby być albo było ${ }^{37}$.

Dosłownie ogień jest nam bliski

Czasami czujesz go w podeszwach stóp.

To znak, że kiedyś wszystko było boskim oceanem

Zaś głęboki czas ziemi wyraża się w liczbach tak zatrważających,

Że ich odkrycie odmieniło bieg ludzkich myśli.

Która rzecz jasna, spodziewa się gruntu

Pod nogami i przychylnej aury

Z tej perspektywy słońce jest czymś w rodzaju wieczności,

A może upartym podtekstem

(Planeta rzeczy zagubionych, 5)

W wierszach Fiedorczuk ujawnia się przeczucie, że granice między ludzkim i nie-ludzkim są płynne. W tej wizji krzyżują się światy kultury, fantazji i natury, skutkiem czego wiedza, podsycana wyobraźnią, podsuwa obrazy przekształcające to, co jest, w to, co możliwe. Jacob nazywa tę modalność „grą możliwości"38. Nasze emocje: żądze, obawy, lęki i ciekawość są czynnikami dynamizującymi albo uniemożliwiającymi tworzenie takich splotów możliwości i byłości ${ }^{39}$. O płynności granic między światami, np. między ludzkim i nie-ludzkim, świadczą ryby, a zwłaszcza syrena, która jest figurą przejścia z jednej formy do drugiej. Już Owidiusz pisał, że „nasze własne ciała podlegają wciąż nieustannym zmianom, i nie jesteśmy tym, czym byliśmy lub czym będziemy jutro" ${ }^{\text {40 }}$.W tej sferze granicznej, którą rządzi labilność, panuje inny porządek czasowy: stare i nowe, następujące zazwyczaj po sobie, istnieje obok siebie i niezmieszane tworzy nowe jakości. Różne przejawy istnienia mogą się ze sobą łączyć, współistniejąc na zasadzie pewnej ugody ${ }^{41}$.

37 J. Fiedorczuk Lądyi oceany, w: tejże Planeta rzeczyzagubionych, Biuro Literackie, Wrocław 2006, s. 5.

F. Jacob Gra możliwości. Esej o różnorodnościżycia, przeł. M. Kunicki-Goldfinger, PIW, Warszawa 1987.

A. Wieczorkiewicz Monstruarium, słowo/obraz terytoria, Gdańsk 2009, s. 276. 
Fantazja o rybich korzeniach, w sferze wizualnej przyjmująca postać skrzyżowania kobiety i ryby, nie jest ślepym przypadkiem, szaleństwem wyobraźni, ale świadectwem innego porządku, a także głębinowym wspomnieniem przejścia z jednej formy życia w drugą:

Tamte podskórne

Czasy podpływają bliżej. Są moje

Na ułamek światła, momentalny bezdech

I rozkoszny strach, który się zaraz rozproszy

W musującej toni, $[\ldots]$

$(B i o, 6)$

Czyż nie należy się zgodzić, że ogon ryby/syreny jest bolesnym znakiem przejścia w samej przyrodzie, ale także stanem pośrednim między naturą i kulturą, sztuką a techniką? Wskazuje on także na fakt, że każda żywa istota zbudowana jest z zapożyczonych materiałów, a śmierć, jak pisze Louis-Vincent Thomas, jest właśnie ich zwrotem, czyli rozdzieleniem elementów. Każda istota jest więc tylko ogniwem pośrednim i czasowym w nieskończonym łańcuchu życia ${ }^{42}$. Julia Fiedorczuk w wierszu Kochankowie na otwartym morzu pisze:

To jest planeta zagubionych rzeczy

I ja jestem jedną z nich, pomyślała. Znów mam płetwy. Ruch Jest łatwy jeśli jest ślizem, łatwy, kiedy się jest gołębiem w powietrzu Wykonującym ślizg. Wszystko jedno życie, kiedy na niego czeka i mówi "teraz jestem twoja, należę do ciebie, należę do morza, do ziemi, do ciebie"

(Planeta rzeczy zagubionych, 31)

Wyobrażenie pół kobiety, pół ryby jest częścią działania kultury, ale też zapisem doświadczenia przekazywanego od milionów lat. Odwołując się do gry możliwości i będąc przeświadczonym o bliskości gatunków, Italo Calvino we Wszystkich opowieściach kosmikomicznych przedstawia historię o wujku-rybie i jego rodzinie, która wyszła na ląd i tam, rezygnując z wodnego życia, zamieniła płetwy na nogi. Ku zdumieniu głównego bohatera opowiadania,

42 L.-V. Thomas Trup: od biologii do antropologii, przeł. K. Kocjan, Wydawnictwo Łódzkie, Łódź 1991, S. 27. 
zachwyconego życiem na lądzie, jego narzeczona pod wpływem opowieści wujka, który pozostał rybą, postanawia wrócić do wody ${ }^{43}$.

We współczesnej nauce rozeznanie Darwina, że zmiany form dokonują się przypadkowo, a metamorfozy nie da się wyjaśnić jakimś ogólnym zamysłem natury, jest nadal aktualne. Przyroda wykorzystuje to, co istnieje, wybierając przypadki korzystne, a więc udoskonalenie i degeneracja są zachowywane bądź usuwane ${ }^{44}$. W wierszu Elektryczność pojawia się ta intuicja:

Pod spodem płetwy

Przetną kryształ wody

Jeszcze pluśnie ogon,

Potem przepadnie w zieleni, zwinna

Jak iskra (rozżarzona cząstka

Płonącego ciała, oderwana od całości).

$($ Bio, 11)

To wspomnienie z dalekiej przeszłości opisane przez Calvina, a także przez Fiedorczuk każe nam myśleć, że nie tylko ryba, syrena, ale każda żywa istota jest formą przejściową, a przez to otwartą na zmiany ${ }^{45}$. Margrit Shildrick uważa, że ciało jest niestabilne, i chociaż materializuje się, ma płeć, ale zawsze, używając jej określenia - „przecieka”.Ta płynność, niestabilność, dzikość reprezentowana przez kobiety z ogonami oznacza również powiązanie z innymi ciałami. Marzenie o byciu rybą/syreną opiera się na „radykalnym otwarciu na wielorakie możliwości stawania się"46. W podobny sposób ujmuje proces „współpowstawania” Fiedorczuk. Postuluje ona rozszerzenie naszego widzenia człowieka na to, co go otacza i w niego wnika. Woda, powietrze, rośliny, zwierzęta są częścią nie tylko naszego bytowania, ale również naszego ciała ${ }^{47}$.

Być może wzorem dla Calvino były aksolotle (ambystoma meksykańska), płazy, które w warunkach wodnych zaczynają zachowywać się jak ryby. Obecnie wiadomo, że z ryb trzonopłetwych (latimeria) powstały płazy tarczogłowe, a Ichtiostega jest taką formą pośrednią. Nieliczne płazy w dewonie przystosowały się do życia lądowego, dając początek gadom. Niektórzy zoologowie uważają, że adaptacja do warunków lądowych była niejako przypadkowa i uboczna w stosunku do migracji i zdolności kolonizowania nowych wysp siedliskowych, jakimi były wody stojące.

A. Wieczorkiewicz Monstruarium, s 163.

J. Żylińska Bioetyka w epoce nowych mediów, Wydawnictwo IBL PAN, Warszawa 2013, s. 15.

Tamże, s. 52-53.

Zob. https://przekroj.pl/artykuly/felietony/o-wszechprzenikaniu-julia-fiedorczuk. 
Gilles Deleuze przedstawia propozycje nowej etyki, która skupia się na „stawaniu się ciała" raczej niż na ustalonym, niezmiennym podmiocie ludzkim. Uważa on, że należy poszerzać strumień życia, otwierając się na to, co nieludzkie, i wykraczać poza możliwości już przez ludzi wyobrażone ${ }^{48}$. Jego założenia wydają się bliskie podejściu Fiedorczuk, widzącej świat jako jedność materii ożywione i nieożywionej:

Słowem się spotkamy

Gdzie kończy się ciało

W ciepłych łezkach ziemi

W czarnych

Piórach fali

Tej upartej

Która jednak

Musi się wygładzić

$($ Bio, 21)

Koncepcja „stającego się ciała” jako maszyny zdolnej oddziaływać i poddanej oddziaływaniom, zanurzonej w strumieniu życia jest przedmiotem zainteresowania badaczy nowych technologii. $\mathrm{W}$ procesie biotechnologicznym elementy żywe i nieżywe wchodzą z sobą w intymne związki. Punktem odniesienia może być sama materia, która bez względu na to, czy nieożywiona czy żywa, ciągle organizuje się i tworzy systemy ${ }^{49}$. Joanna Żylińska pisze, że „alianse (organiczno-nieorganiczne) proponowane przez biotechnologie pokazują, że istnieje wzorzec unieważniający zarówno wyobrażenie o życiu jako o czymś, co wnika w maszynę, aby ją napędzić, jak i wyobrażenie o technice, jako o czymś dodanym post factum do pierwotnie żywej jednostki" ${ }^{50}$.

Życie rozumiane jako manifestacje dzikości i proces techniczny włączający wszystkie historyczne, genetyczne, afektywne inwestycje zakłada też kreatywność, czego świadectwem jest poezja Fiedorczuk. Podstawą jej twórczych poszukiwań jest również wykorzystywanie istniejących już elementów, dopasowywanie ich przez zmianę formy i układanie ich w różnorodne kombinacje, a w efekcie wytwarzanie nowego języka i tworzenie innych niż dotychczasowe

\footnotetext{
48 J.Żylińska Bioetyka wepoce nowych mediów, s. 53-54.

49 F. Jacob Gra możliwości..., s. 51.

50 J.Żylińska Bioetyka w epoce nowych mediów, s. 4.
} 
środków wyrazu. W poezji, sztuce, takjak w ewolucji, genetyce i technologiach panuje więc odwieczny dziki, pełen bólu bricolage ${ }^{51}$. I w tym sensie rybi/syreni ogon - żywy czy sztuczny - jest użytecznym elementem, który może być dołączony do innego ciała, co w konsekwencji zawsze daje zaskakujące efekty.

Doskonale rozumiała to Magdalena Abakanowicz. Komentując swoją pracę Gry wojenne, wyznała, że długo postrzegała drzewa jako „skończone osobowości", ale przyszedł w końcu moment, gdy przejrzała. Zaczęła widzieć podobieństwo między wszystkimi tworami natury. Zrozumiała, że natura w jakiś sposób ograniczona, projektuje samą siebie. Rzeźbiarka poczuła, że chce ingerować, postanowiła dodać do pni ściętych drzew inny materiał; zestawiając drzewo i żelazo stworzyła więc formę hybrydyczną, syrenią ${ }^{52}$. Parę lat później przebywała na Mazurach i, jak wspomina, zaskoczyły ją „, cielska muskularne, okaleczone, pełne siły i osobowości. Leżały prężąc kadłuby, amputowane kończyny, patetyczne w gestach - nie wiadomo: cierpienia, protestu czy bezradności. Chciałam je dotykać, poznawać szczegóły kształtów, aby je przeistoczyć, przenieść w inne trwanie"53.

Takie rozumienie syreniego bricolage'u bliskie jest też innym artystkom wizualnym, które w swoich artystycznych przedsięwzięciach pragną zwrócić uwagę na fałszywą grę Europy ukrywającą niechęć wobec migrantów, próbujących przedostać się na stary kontynent i na obojętność demokratycznych państw wobec zmian klimatycznych. 30 maja 2017 roku w ramach wystawy Syrena herbem twym zwodnicza odbywającej w Muzeum Sztuki Nowoczesnej w Warszawie odbył się performans Ciagle ten sam śpiew Europy Oli Kozioł. Artystka wcieliła się w Syrenę-Europę, śpiewającą swoją urzekającą, zwodniczą pieśń. W autorskim komentarzu artystka tak objaśniała swoje działanie: „Kiedy myślę o tym, kim jest syrena dziś, widzę ją jako Europę, kuszącą, nawołującą do przepłynięcia przez morze wszystkich ludzi uciekających przed wojną, suszą, biedą, szukających nowego, lepszego życia. Europę, która wabi pieśniami o lepszym świecie, sprowadza do swoich brzegów, ale nie daje nic, poza możliwą śmiercią podczas podróży"54.

51 F. Jacob Gra możliwości..., s. 65-66.

52 W. Krukowski, M. Abakanowicz Magdalena Abakanowicz, Centrum Sztuki Współczesnej Zamek Ujazdowski, Warszawa 1995, s. 156.

Tamże, s. 161. Barbara Jędraszko zwróciła mi uwagę, za co jej bardzo dziękuję, na podobieństwa między pracą Abakanowicz i Schlachtfeld, pracą Miriam Cahn, której wystawa I AS HUMAN odbyła się w MSN jesienią 2019 roku w Warszawie. 
Agnieszka Zawadowska w swoim niepublikowanym komentarzu do tego performansu zwraca uwagę na nowe oblicza syren. Do tej pory strzegły one mostów, miast, państw, domów, kościołów, teraz według niej same znalazły się za drutami obozów, wysokimi murami, a ich ogony pełne są plastikowego szlamu, śmieci i zdechłych ryb. Czasami ich ogon staje się torbą z Ikei wyrzuconą na śmietnik albo podartym śpiworem bezdomnego bądź migranta, któremu udało się przedostać do wymarzonego świata. Według artystki kraje Europy pozbawione są współczucia i nie chcą się z nikim dzielić, przeczuwając swój własny kres, oddają się dekadenckiemu marnotrawstwu. Zesztywniały ogon na wysypiskach śmieci uniemożliwia syrenie powrót do wody. Powrót z resztą jest bezzasadny, morza są zatrute, a rzeki wysychają.

Hybrydyczność spotykamy wszędzie, sami też wraz z rozwojem technologii staliśmy się hybrydami, żeby nie powiedzieć, że zawsze nimi byliśmy. Protezy, których używamy nawet jako zdrowi ludzie, czynią nas formami o skomplikowanej budowie.W przeszłości człowiek na koniu był postrzegany jako coś dziwacznego, a centaury, żeby stać się postaciami z komiksów, odbyły długą podróż do środka naszej wyobraźni zbiorowej. Obecnie nie wyobrażamy sobie codziennego funkcjonowania bez samochodów, komputerów i smartfonów. Nasze życie codzienne, myślenie, twórczość, fantazje opierają się na mechanizmach scalania różnych elementów. Nie jest to dobre ani złe. Bo czyż nasza umiejętność liczenia i tworzenia całości, nasza skłonność do przechodzenia od ilości do jakości czy zamiłowanie do gry z metaforami jest czymś niestosownym? Nie musimy nawet odpowiadać na te pytania. Traktujemy te czynności jako przyrodzone, potrzebne, dobre, a czasami piękne. Niebezpieczeństwo kryje się w naszym idealizmie, w dążeniu za wszelką cenę do perfekcji.Zaspokajamy się łatwymi dualizmami, pozornie porządkującymi naszą rzeczywistość.

Marzenia o symetrii i jedności świata przesłaniają nam oczy i nie pozwalają nam postrzegać świata jako niedoskonałego, zbudowanego z nietrwałych, niepasujących do siebie części. I robimy wszystko, żeby nasze widzenie było pozbawione wątpliwości, niepokoju, a wszelkie zanieczyszczenia są automatycznie usuwane. A świat warto oglądać, jak pokazuje poezja Fiedorczuk, na kilku poziomach jednocześnie:

co nas w mroku łączy, rozdziela i łączy, łączy, rozdziela i łączy; zaczyn nowego dnia.

(Matematyka, Tt) 
W rozmowie z Darią Lekowską autorka tuż-tuż powiedziała: „poezja zawsze się sytuowała na granicy wypowiadalnego i niewypowiadalnego. Metafora nieco podobnie, przez to, że łączy ze sobą odmienne rzeczy - czasami przeciwieństwa - jednocześnie nie zlewając ich w jedno"55.

Cała twórczość Fiedorczuk zachęca, żeby w postaciach hybrydalnych i idealnych widzieć rozłączenia, połączenia i to, co pozostaje na obrzeżach i ukrywa się w głębi, ponieważ dzięki temu wyostrza się nasza wrażliwość i odsłaniają się syrenie miejsca, które zachowują bolesną pamięć o poprzednim życiu i moment przejścia w inny stan, poddający się sile zapomnienia.

\section{Abstract}

\section{Monika Rudaś-Grodzka}

THE INSTITUTE OF LITERARY RESEARCH OF THE POLISH ACADEMY OF SCIENCES (WARSAW)

Syrenism: The Poetry of Julia Fiedorczuk

Rudaś-Grodzka explores the different functions of myth in the poetry of Julia Fiedorczuk (born 1975), which can be seen as one of the most interesting artistic developments in Poland today. Fiedorczuk is a literary scholar and translator and her work draws on American Modernists, ecocriticism and feminism. Rudaś-Grodzka explores Fiedorczuk's poetic strategy, which on many semantic levels is characterised by hybridity. RudaśGrodzka also proposes the concept of syrenism, understood as a creative stance that opposes unifying or bonding forces, which give rise to a continuum and symmetry.

\section{Keywords}

syrenizm, hybridity, ecopoetry, remythologisation

55 D. Lekowska, J. Fiedorczuk Potrzebujemy żywotnej, empatycznej wyobraźni. Rozmowa Darii Lekowskiej z Julią Fiedorczuk, "Czas Kultury” 2017 nr 2, s. 120. 